\title{
THE CATALOGUE OF FRESHWATER DECAPODA (DECAPODA: POTAMONIDAE, ASTACIDAE, ATYIDAE) FROM THE REPUBLIC OF MACEDONIA IN THE COLLECTION OF MACEDONIAN MUSEUM OF NATURAL HISTORY
}

\author{
Valentina Slavevska-Stamenković ${ }^{1 *}$, Biljana Rimčeska ${ }^{1}$, Emilija Stojkoska $^{2}$, Nataša Stefanovska $^{2}$, \\ Jelena Hinić1, Vasil Kostov ${ }^{3}$
}

${ }^{1}$ Institute of Biology, Faculty of Natural Sciences and Mathematics, Ss. Cyril and Methodius University, Skopje, Republic of Macedonia

${ }^{2}$ Macedonian Museum of Natural History, Skopje, Republic of Macedonia

${ }^{3}$ Fisheries Department, Institute of Animal Science, Ss. Ciril and Methodius University, Skopje, Republic of Macedonia

"Corresponding author: vstamen@yahoo.com

\begin{abstract}
The catalogue summarizes the data found in the collection of freshwater decapods of the Macedonian Museum of Natural History in Skopje, Republic of Macedonia. In the present work we have also critically reviewed the historical data on the occurrence and distribution of representatives of decapods present in the country. The populations of decapods have never been intensively studied in Macedonia, and thus, this catalogue may serve as a valuable source of data for nature conservation and protection of crustaceans and their habitats.
\end{abstract}

Key words: catalogue; Decapoda; Macedonian Museum of Natural History; Macedonia

\section{INTRODUCTION}

Freshwater decapods are a highly diverse group of crustaceans currently known from all biogeographical regions (except Antarctica and India for crayfishes). Among an estimated number of 3.000 described freshwater decapod crustaceans, about 640 species can be considered as crayfish species (Astacidea) [1, 2]. A total of 655 freshwater shrimps (Caridea) and 1.300 freshwater crabs (Brachyura) are presently known [3, 4]. The key processes driving decapod crustaceans diversification are likely to be habitat heterogeneity, high diversity of ecological niches in freshwater ecosystems and frequent genetic isolation between populations $[1,3$, 4]. Relatively low fecundity and poor dispersal abilities, probably, contributed to the evolution of rich assemblage of freshwater decapods [2].

There are scarce published data about the decapod fauna (Crustacea: Decapoda) from the Re- public of Macedonia. The oldest data are from the 1920's, when Balss [5] registered three species for the country. On the basis of morphological criteria Karaman S. [6] gave a description of two crayfish subspecies, Astacus astacus balcanicus S. Karaman, 1929 (under synonymic name Potamobius fluviatilis balcanicus S. Karaman, 1929) and Austropotamobius torrentium macedonicus S. Karaman, 1929 (under synonymic name Potamobius torrentium macedonicus S. Karaman, 1929) in his review of freshwater decapods (Astacidea: Astacidae) in former Yugoslavia. According to Karaman S., A. t. macedonicus represents a national (Macedonian) endemic crayfish restricted to the River Vardar drainage. Few decades later, the most widely accepted taxonomic studies by Karaman M. [7, 8] recognized three subspecies of crayfish Astacus astacus (Linnaeus, 1758), confirming the presence of subspecies $A$. $a$. Balcanicus in the Western Balkans, in the drainage 
system of the River Vardar in the Republic of Macedonia and Greece, as well as in Ohrid Lake. It must be emphasized that the taxonomic status and distribution of A. a. balcanicus and A. t. macedonicus has been discussed by many researchers (e.g. [9-11]) and still has not been fully resolved. Herein, we accept taxonomic studies by Karaman M. [7, 8, 12].

Concerning the freshwater crabs (Brachyura: Potamonidae), a more detailed research on taxonomy and distribution in Macedonia was conducted during the 1960's by Preitzmann [13] and Bott [14]. The first information about shrimps (Caridea: Atyidae) on the territory of the country was published by Karaman M. [15]. He described new subspecies named Atyaephyra desmaresti stankoi Karaman, 1972 (synonym of Atyaephyra stankoi Karaman, 1972) from material collected from Dojran Lake (Macedonia). Furthermore, Karaman M. [12] summarized and critically reviewed the existing data on taxonomy, biology, distribution and phylogeny of decapods (Potamonidae, Astacidae, Atyidae) inhabiting freshwaters in Macedonia. Recently, important nomenclatorial and taxonomic changes have been introduced in Decapoda systematics, mainly in the family Atyidae [16, 17], which contributed for updated checklist of freshwater decapods in the country [18].

Republic of Macedonia is one of the European countries where non-indigenous crayfishes, crabs and shrimps have not been introduced. According to Karaman M. [12] and Christoudoulou et al. [16] five indigenous decapod taxa (species and subspecies) occur in freshwater habitats in the country: noble crayfish Astacus astacus balcanicus S. Karaman, 1929; stone crayfish Austropotamobius torrentium macedonicus S. Karaman, 1929; freshwater crabs Potamon fluviatile (Herbst, 1785) and P. ibericum (Bieberstein, 1809); and freshwater shrimp Atyaephyra stankoi Karaman, 1972. However, insufficient information on the distribution of decapod representatives from the territory of Macedonia is available at present. Additionally, crayfishes, crabs and shrimp, like the freshwater habitats in which they are encountered, receive relatively little publicity and conservation attention in the country, in spite of their key role in the aquatic food webs and ecosystem functioning.

The aim of this study is to create a catalogue based on specimens stored in the collection of the Decapoda of the Macedonian Museum of Natural History $(\mathrm{MMNH})$, in Skopje, Macedonia. In the present work we have also critically reviewed the historical data on the decapods of Macedonia. The catalogue contributed to update our knowledge on the geographical distribution, ecology and taxonomy of the freshwater decapods in Macedonia and will serve as a valuable source of information for nature conservation and the protection of decapods and their habitats.

\section{MATERIAL AND METHODS}

The current review of freshwater decapods is based on available literature data and studied material deposited in MMNH. The collection of Decapoda comprises 258 specimens gathered during a period of almost 70 years (from 1946 to 2015). Decapod crustaceans are chronologically registered and separately numbered with inventory numbers. The specimens are in a very good state of preservation in $70 \%$ ethanol. In addition, valuable material of crayfishes was donated by V. SlavevskaStamenković in 2016 (collected during 2008-2016). All specimens were revised by the first author following the keys by Pârvulescu [19], Zaikov [20] for crayfishes and Karaman M. [12] for crabs. The redescription presented in Christodoulou et al. [16] was used for confirmation of the freshwater shrimp Atyaephyra stankoi in the collection of MMNH.

The catalogue comprises the following data: Valid taxa name, Published records, Material studied and Remarks.

The systematic presentation of taxa (species and subspecies) follows Karaman M. [12], De Jong et al. [21] and Christoudoulou et al. [16]. Below the valid taxa name are listed chronologically, the original names under the taxon which was cited in literature. The genera and species are arranged alphabetically within each family.

Published records are cited in a shortened form including the respective reference, name of the watercourse and adjacent settlement or mountain. Additional information may be found in original papers.

New distributional records (Material studied) are presented in the following sequence: name of watercourse, name of adjacent settlement, date of collection, number of specimens and sex (only for crayfish specimens), name(s) of collector(s), inventory numbers of the specimens deposited in MMNH (in square brackets). The geographic information and date of collection are omitted when missing. Records are arranged according to inventory numbers.

Additional information concerning ecology, distribution, population status, threats and taxonomic changes could be found in paragraph remarks. 


\section{Abbreviation used in this cataloggue}

Legator names: Biljana Rimčeska - BR, Despina Kitanova - DK, Djoko Djorgievski - Dj Dj, Emilija Stojkoska - ES, Irina Šoreva - IS, Jovan Kuševski - JK, Kiro Bogoevski - KB, Ognjanka Popovska - OP, Risto Grupče - RG, Svetozar Petkovski - SP, Snežana Stanković - SS, Trajan Petkovski - TP, Vasil Kostov - VK, Valentina Slavevska Stamenković - VSS and legator unknown- LU.
Other abbreviations: $\hat{\delta}-$ male specimen(s), + - female specimen(s), s. - $\operatorname{specimen}(\mathrm{s})$, v. village, Mt. - mountain, leg. - legator(s).

\section{THE CATALOGUE PRESENTATION}

The catalogue presented herein includes data on five decapod taxa (Figure 1), including Brachyura (2), Astacidea (2) and Caridea (1). The nomenclature used in this section follows the decision of the International Commission on Zoological Nomenclature (ICZN 2000).
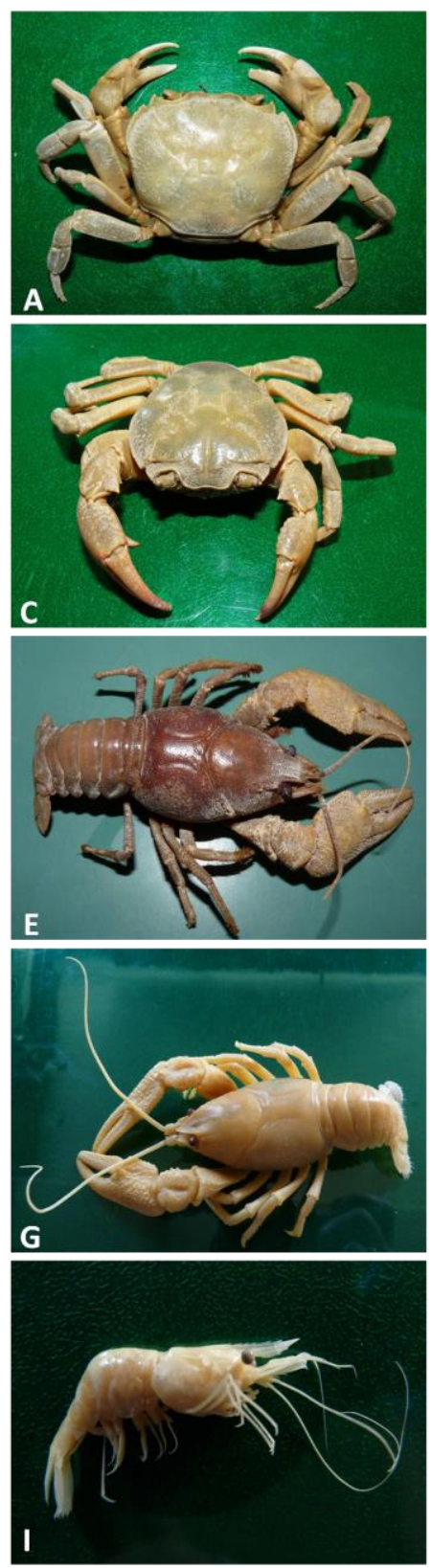
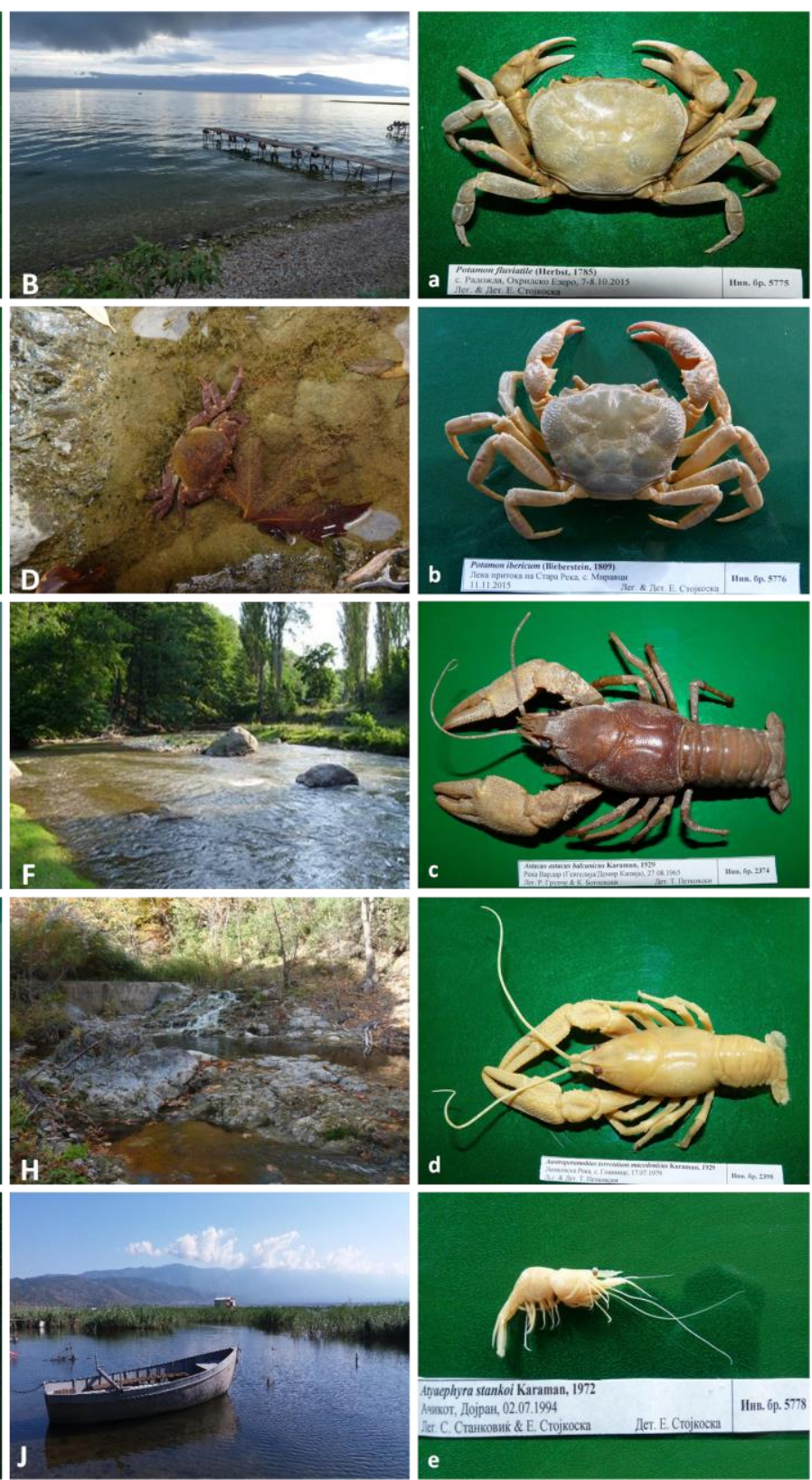

Figure 1. A-B: Potamon fluviatile (A) and its habitat from Ohrid Lake, v. Radožda (B); C-D: Potamon ibericum (C) and its habitat from the Stara River, v. Miravci (D); E-F: Astacus astacus balcanicus (E) and its habitat from the Pčinja River close to MacedonianSerbian border (F); G-H: Austropotamobius torrentium macedonicus (G) and its habitat from Mt. Galicica (H); I-J: Atyaephyra stankoi (I) and its habitat from Dojran Lake, Macedonia (J); a-e. The studied species from MMNH with inventory numbers. 
Order DECAPODA Latreille, 1802

Suborder PLEOCYEMATA Burkenroad, 1963

Infraorder BRACHYURA Linnaeus, 1758

Family Potamonidae Ortmann, 1896

\section{Genus Potamon Savigny, 1816}

Potamon fluviatile (Herbst, 1785)

= Cancer fluviatile Herbst, 1785

= Potamophilus edule Latreille, 1818

= Potamon (Eutelphusa) edule Pretzmann, 1962

= Potamon (Telphusa) fluviatilis Pretzmann, 1983

Published records: Karaman M. [12]: Ohrid Lake's tributaries and springs (rare on the shore line), Crn Drim watershed.
Material studied: Ohrid Lake, v. Radožda, 7-8.10.2015, 11 s., leg. ES [5775].

Remarks: The freshwater crab Potamon fluviatile (Figure 1: A, a) was the first described species from the Eurasian genus Potamon [22]. Because the species was extremely used for human consumption, the former species' name was $P$. edule (Latin word "edulis" = edible) [23]. P. fluviatile has a highly fragmented geographic distribution over a wide area in a number of countries that have a Mediterranean coastline [24]. This species inhabits unpolluted rivers, streams and lakes throughout its range. Resent ecological survey by Barbaresi et al. [25] suggested that the populations of P. fluviatile have declined dramatically as a result of pollution, regulation and desiccation of streams, overexploitation for human consumption and introduction of exotic crayfish species.

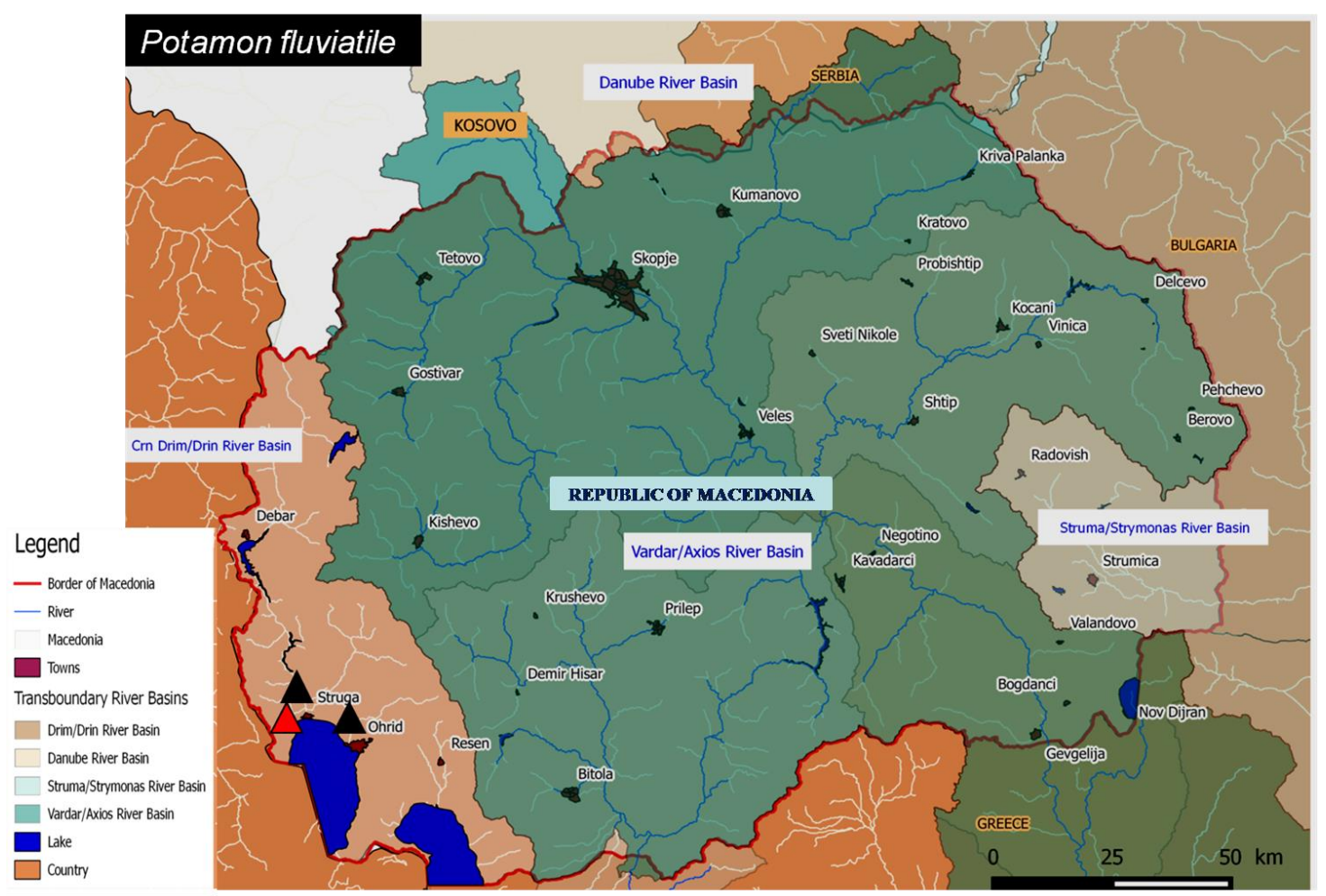

Figure 2. Distribution of Potamon fluviatile in Macedonia. Black triangles = published records, red triangles = material studied

Although in IUCN Red List of Threatened Species is listed as "Near Threatened" (Table 1), it is possible that the species is under higher risk of extinction on global scale $[24,25]$ and thus in Macedonia too. Bearing in mind that the species has a narrow geographical distribution in our country (Ohrid Lake watershed; Figures 1, 2), in our opinion, the protection should be strongly regulated on national level of legislation. Habitat protection and preservation of freshwater ecosystems are obviously the main goal for conservation of $P$. fluviatile in Macedonia.

\section{Potamon ibericum (Bieberstein, 1809)}

= Cancer ibericum Bieberstein, 1809

= Thelphusa intermedia taurica Czerniavsky, 1884

= Potamon (Pontipotamon) ibericumtauricum Pretzmann, 1962 
Published records: Karaman M. [12]: Dojran Lake spring near Toplec, lower part of the River Vardar and its tributaries, springs on Mt. Gradeška, Gevgelija valley.

Material studied: Dojran Lake, 7 s., leg. LU [2377]; 4 s., leg. LU [2391]; Gabrovo stream, 22.04.1986, 2 s., leg. SS [2392]; Dojran Lake, spring near Toplec, 28.06.1986, 2 s., leg. SS [2393]; Dojran Lake, spring near Toplec, 09.09.1988, 7 s., leg. SS [2397]; Dojran Lake, spring near Toplec, channel besides spawning place, 11.06.1997, 3 s., leg. SS [2773]; stream near v. Balakli, Mt. Gradeška, 08.05.2012, 1 s., leg. ES [5773]; Konjska Reka river, under v. Gorničet, Mt. Kožuf; 11.09.2000, 1 s., leg. ES [5774]; Stara River, v. Miravci, 11.11.2015, 2 s., leg ES [5793], Konjska Reka river, v. Konjsko, Gevgelija, 12.11.2015, 6 s., leg. ES [5794].

Remarks: Similar to P. fluviatile, freshwater crab P. ibericum (Figure 1: C, b) has a wide and highly fragmented distribution. Due to human impact there has been a distinct decline in population abundance in most parts of its range since the mid 1970 's, and in some places the populations of crabs may have already disappeared [24]. Mainly, the populations are threatened by water pollution, nonpurified sewages and habitat destruction, such as river-bed straightening, building of reservoir, withdrawal of water for local needs, stream channelization. Further, freshwater crabs are an important protein source and are consumed in many parts of its range [4], which significantly contributed to the decline of the populations of $P$. ibericum. Therefore, IUCN Red List of Threatened Species (Table 1) assessed the species as Near Threatened (NT), with an indication that in the future it may be close to qualifying as Vulnerable (VU) under A2 [24].

The results of this study show that in the last twenty years no specimen of $P$. fluviatile was registered in the springs near Toplec, Dojran Lake, Macedonia (Figure 3). It is possible that habitat alteration of the springs caused extinction of subpopulations of the species. In this connection we strongly recommended urgent protection of the species, at least under national regulations. Unfortunately, protection limited to local regulations often is not sufficient to preserve the species from decline.

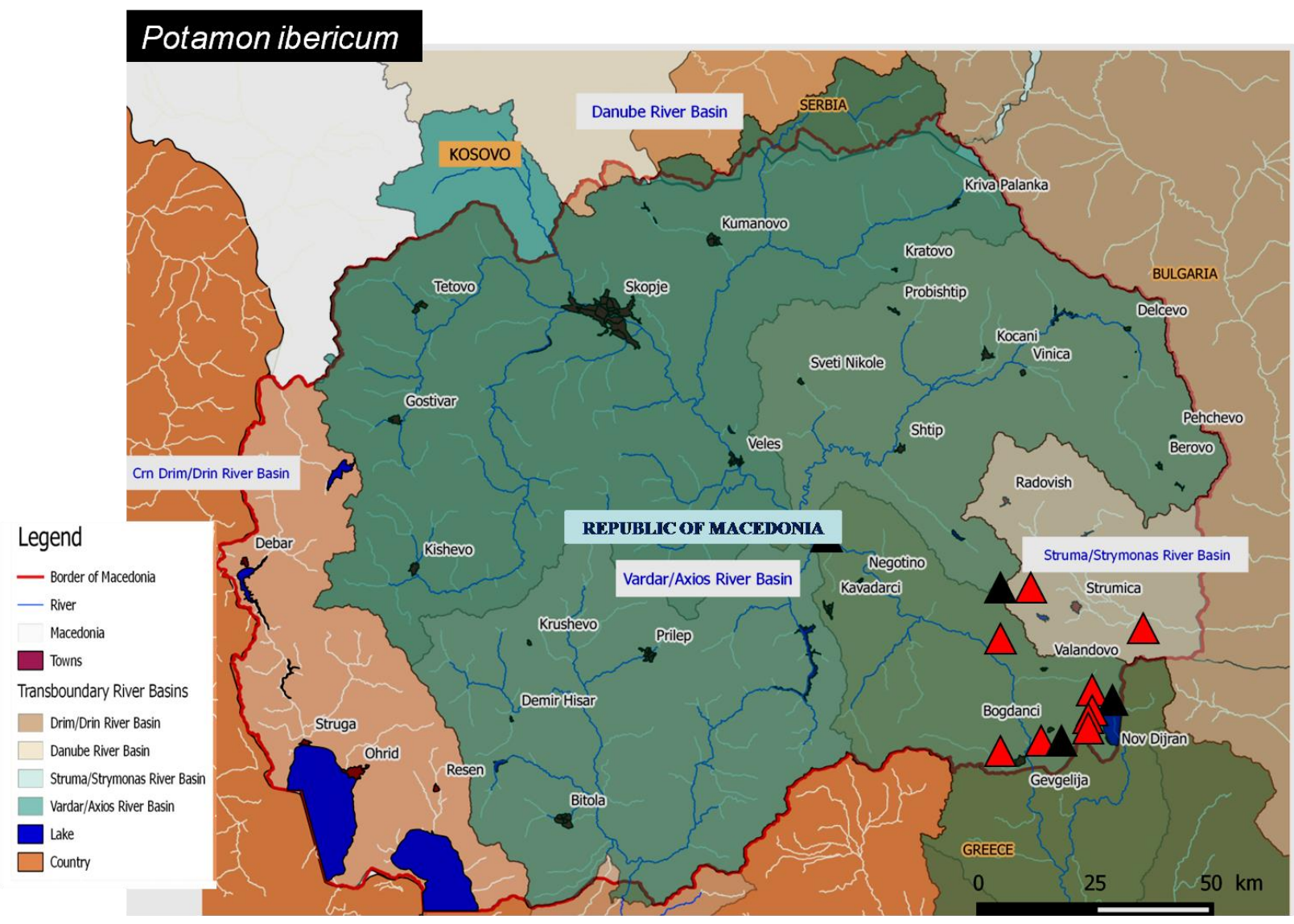

Figure 3. Distribution of Potamon ibericum in Macedonia. Black triangles = published records, red triangles $=$ material studied 
Inf raorder ASTACIDEALatreille, 1802

Family Astacidae Latreille, 1802

Genus Astacus Fabricius, 1775

1929

Astacus astacus balcanicus S. Karaman,

= Potamobius fluviatilisbalcanicus S. Kara-

man, 1929

= Astacus colchicus balcanicus M. Karaman,

1961

= Astacus (Astacus) astacus balcanicus M.

Karaman, 1963

Published records: Karaman S. [6]: Ohrid Lake, Vardar River watershed; Holothuis [26]: Vardar River near Vazarci south of Skopje; Albrecht [9]: Ohrid Lake, Sateska River; Subchev \& Gelder [27]: Dojran Lake, Skopje.

Material studied: Vardar River, Demir Kapija, Gevgelija, 27.08.1965, 5ðへ, 7우, leg. KB, RG [2373]; Vardar River, Demir Kapija, Gevgelija,

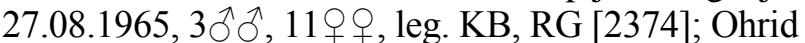
Lake, 20.07.1965, 4§ึ, leg. TP [2375]; Struga,

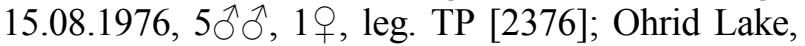
20.07.1965, 12 $\widehat{\partial}$, leg. TP [2378]; Dojran Lake,
$3 \widehat{\jmath}, 1$, leg. LU [2390]; Bregalnica River, v. Razlovci, 10.1985, 5 s., leg. JK [2399]; Mavrovica Reservoir, Sv. Nikole, 10.2013, 2ð̋̄, 2 우, leg. VSS, VK [5770]; Pčinja River, near border with Serbia, 18.07.2009, 1ð, leg. VSS [5785].

Remarks: Astacus astacus (Figure 1: E, c) is indigenous and widespread crayfish throughout Europe [28]. This species occurs in rivers, lakes, ponds and reservoirs, where shelter availability like, stones, logs, roots and aquatic vegetation prevail [29]. Populations of noble crayfish are at risk of becoming endangered as a result of various stressors such as: i) habitat alteration and degradation, ii) pollution, iii) increased siltation, iv) overexploitation, v) the virulent disease commonly known as crayfish plague, caused by pathogen oomycete Aphanomyces astaci and vi) competition with invasive non-indigenous crayfish species [30, 31]. Therefore, IUCN Red List of Threatened Species classifies the noble crayfish as a vulnerable species (VU) with a decreasing population trend [32]. The noble crayfish is further included in the Bern Convention (Appendix III) and listed in the EU Habitat Directive 92/43/EEC (Appendix V).

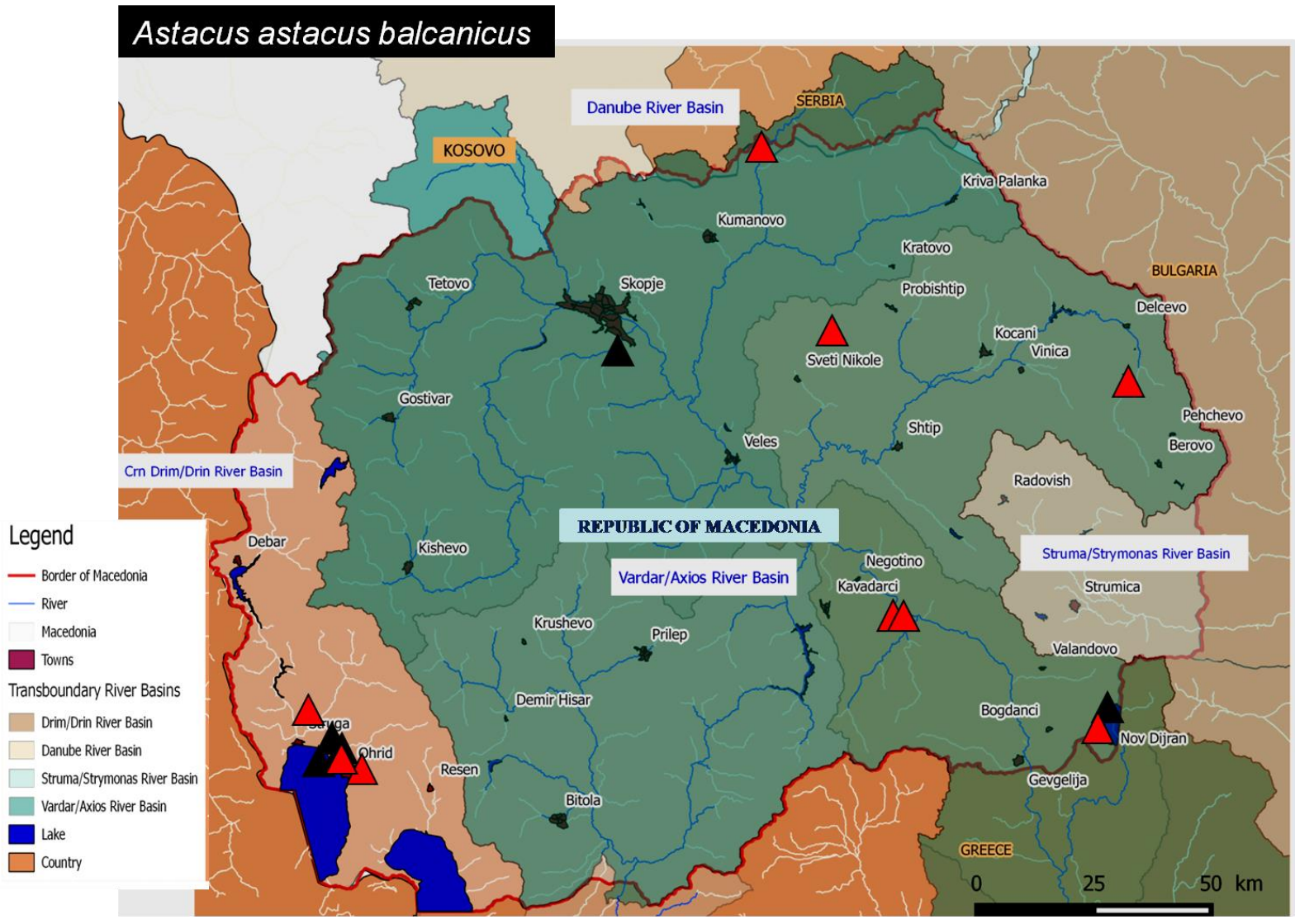

Figure 4. Distribution of Astacus astacus balcanicus in Macedonia. Black triangles = published records, red triangles $=$ material studied 
The results presented in this Catalogue indicate that the current status of the noble crayfish (in Macedonia accepted as A. a. balcanicus) is alarming. In comparison with the stone crayfish, $A$. astacus is rarer, with restricted and fragmented distribution, mainly in the Vardar and Drim drainage systems (Figure 4). Although the species' status is 'protected wild species' in Macedonia, it is only formally protected by local regulations [33].

Moreover, recent molecular-based studies covering a large portion of distribution range of $A$. astacus confirmed that the Balkans were relatively unaffected by geological events during the glacial cycles and that genetic diversity is more conserved in comparison to Central Europe [30, 34]. Taking into consideration that an analysed material from Macedonia is missing, increased data set should be used to resolve the large-scale genetic structure of noble crayfish.

\section{Genus Austropotamobius Skorikov, 1908}

\section{S. Karaman, 1929}

$=$ Potamobius torrentium macedonicus $\mathrm{S}$. Karaman, 1929

= Austropotamobius (Austropotamobius) torrentium macedonicus, Bott, 1950

Published records: Karaman S. [6]: Treska Gorge near Skopje, mountain springs in the Vardar River watershed; Karaman M. [12]: mountain springs without specification of the settlement; Albrecht [9]: Treska River, the village of Bukovo; Subchev [35]: Skopska Crna Gora (Karadah Mt.).

Material studied: Lipkovo, v. Goshince, 19.09.1979, 1ð̂, 2우, leg. TP [2379]; Belchishko wetland, 04.10.1978, 1\%, leg. SP [2380]; Matica

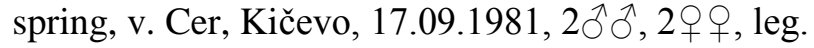
SS [2381]; v. Raec, 19.10.1970, 10, 1웅 leg. TP [2382]; captured spring between v. Bansko and v.

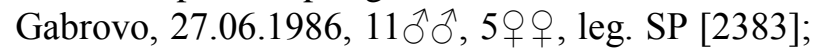
spring before v. Kolešino, 06.06.1986, 2 + $ᄋ$, leg.

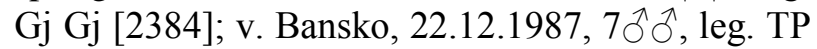
[2394]; spring above v. Smolare, Mt. Belasica, 08.07.1986, 1ठ, leg. SP [2396]; Lipkovska Reka

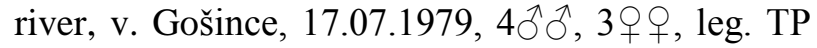
[2398]; Demir Hisar, v. Brezovo toward v. Zasle, 28.07.2013, 19, leg. ES [5771]; Mt. Kozuf, Visoka Čuka (Konjarnik), 17.07.2002, 19, leg. ZN [5772]; Ratevska Reka River, 07.2013, 10, 1ㅇ, leg. VK, VSS [5781]; Orevovečka Reka river, after fishpond, 11.09.2011, 19, leg. BR [5782]; Orevovechka Reka River, after fishpond,
12.08.2011, 1ठ, leg. BR [5783]; Mala Livada River, 11.09.2011, 19, leg. BR [5784]; Bezgašteska Reka river, 30.05.2015, 1ð, 1\%, leg. BR, VSS [5786]; Plavaja river, 06.06.2016, 1 s., leg. BR, VSS [5787]; Zelenogradska Reka river, Mt. Osogovo, 08.2008, 1 s., leg. VSS [5788]; Brajčinska Reka river (upstream), 07.2010, 19, leg. IS [5789]; Zrnovska Reka river, 05.2015, 2 우, leg. VSS [5790]; Bregalnica river, v. Mačevo, 13.06.2015, 10, leg. VSS, DK [5791]; Pehčevska river, 14.06.2015, 19, leg. VSS, DK [5792].

Remarks: A. torrentium (Figure 1: G, d) is relatively widespread crayfish across Europe, confined mainly to higher regions and wooded headwaters, adapted to cold water and rocky environments [36]. This species is reported to be undergoing significant population decline in most parts of its range [37, 38]. Literature data show that the main threats to the population of stone crayfish are the following: i) the presence of non-native species Pacifastacus leniusculus (Dana, 1852) and Orconectes limosus (Rafinesque, 1817); ii) the crayfish plague, caused by pathogen oomycete Aphanomyces astaci; iii) domestic and industrial pollution; iv) habitat loss and degradation (with damming, water abstraction, and channelization of rivers); v) agriculture and vi) eutrophication [37, $38,39]$. However, no quantitative data on the rate of decline is available and therefore IUCN Red list of Threatened Species assessed the species as "Data Deficient" [37]. The European Habitats Directive 92/43/EEC ranks A. torrentium in Annex II among the animal and plant species of Community interest, whose conservation requires designation of Special Areas of Conservation (Table 1). Further, the species is included in Appendix III of Bern Convention and Anex V of EU Habitat Directive 92/43/EEC and presents a protected wild species in Macedonia [33].

Compared to the A. astacus, the stone crayfish (in this Catalogue accepted as A. t. macedonicus) is more widely distributed in Macedonia (Figure 5). Its connectivity with mountainous and wooded headwaters makes it less exposed to anthropogenic pollution and habitat degradation and contributed to its lesser vulnerability. The results presented in this Catalogue contributed to update our knowledge on the geographical distribution of the A. t. macedonicus in Macedonia and will serve as a baseline for the process of designation and establishment of Natura 2000 network in Macedonia. 


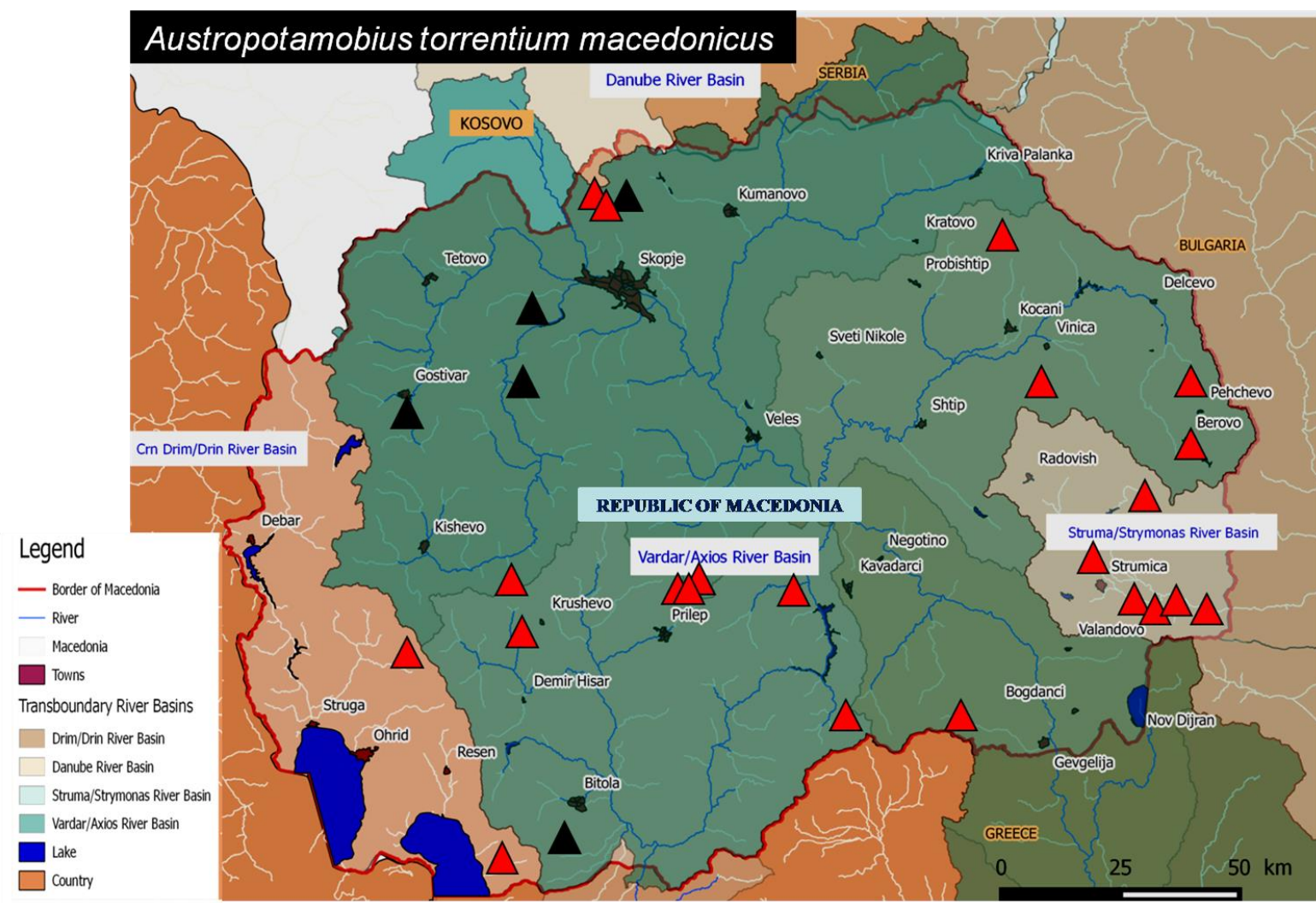

Figure 5. Distribution of Austropotamobius torrentium macedonicus in Macedonia. Black triangles = published records, red triangles $=$ material studied

\section{Infraorder CARIDEA Dana, 1852}

\section{Family Atyidae De Haan, 1849}

\section{Genus Atyaephyra de Brito Capello, 1867}

\section{Atyaephyra stankoi Karaman, 1972}

= Atyaephyra desmaresti stankoi Karaman, 1972

Published records: Karaman M. [15]: Dojran Lake; Karaman M. [12]: Dojran Lake, the channels in Skopje and Pelagonia valleys, downstream of spring Rasče near Skopje; Šapkarev et al. [40]: Dojran Lake near Nov Dojran and Kaldrma; Christodoulou et al.[16]: Dojran Lake.

Material studied: Katlanovo wetland, drainage channel, 22.06.1946, 10 s., leg. KB [2388]; Vardar river, v. Orešani, 13.09.1951, 5 s., leg. KB [2389]; Dojran Lake, 14.09.1972, 3 s., leg. OP [5776]; Dojran Lake, Kaldrma, 01.07.1994, 36 s., leg. ES, SS [5777]; Dojran Lake, Ačikot, 02.07.1994, 7 s., leg. ES, SS [5778]; Dojran Lake, Nikolič, 09.11.1999, 28 s., leg. ES, SS [5779]; Dojran Lake, Mrdaja, 10.11.1999, 10 s., leg. ES, SS [5780].

Remarks: The freshwater shrimp Atyaephyra desmarestii stankoi (Figure 1: I, e) was described by Karaman M. [12] based on specimens from Dojran Lake (Macedonia). Later, García Muñoz et al. [41] argued that the subspecies $A$. d. stankoi actually presents a cryptic species in A. desmarestii complex without confirming its status as a distinct species. Recently, Christoudoulou et al. [16] and García Muñoz et al. [17] confirmed the taxonomical validity of A. stankoi based on morphological and molecular data, after studying specimens from west-central Greece and from the type locality (Dojran Lake). Additionally, the neotype of A. stankoi Karaman 1972, was designated by Christoudoulou et al. [16] to stabilize the species' taxonomy.

A. stankoi is a Balkan endemic species, widespread in west-central Greece, ranging northwards to southern Macedonia (Dojran Lake) [3]. The distribution of this species in Macedonia is presented in Figure 6. The species lives in marginal areas of rivers, lakes and streams and prefers habitats rich with aquatic vegetation [12, 40]. A. stankoi is included in IUCN Red List of Threatened Species as being of Least Concern (Table 1), as no information is provided on population densities and no threats to the species are identified [3]. 


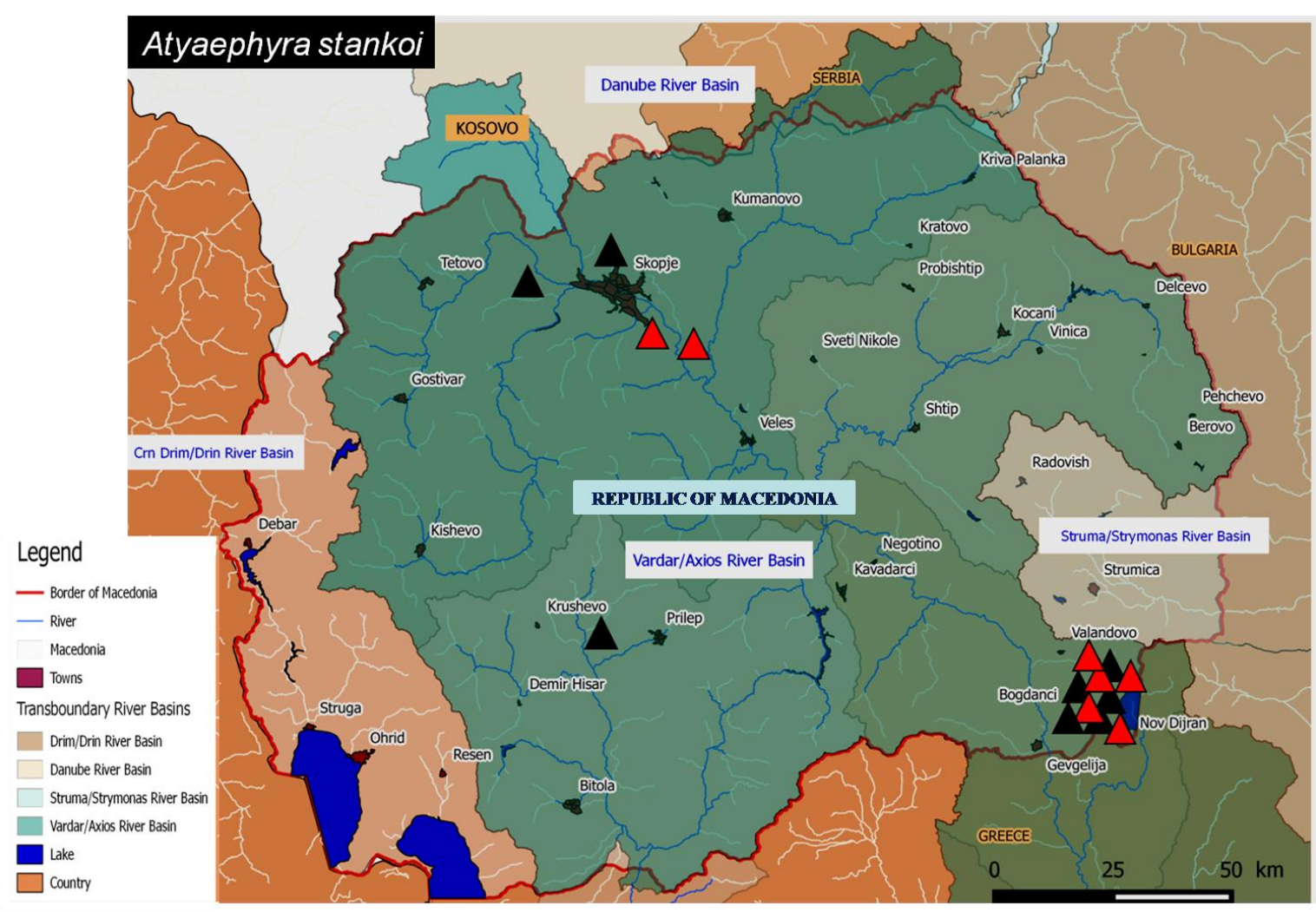

Figure 6. Distribution of Atyaephyra stankoi in Macedonia. Black triangles = published records, red triangles = material studied

Table 1. List of freshwater decapods in Macedonia and their associated status according to national and international criteria

\begin{tabular}{lcccc}
\hline Species & $\begin{array}{c}\text { Habitat Directive } \\
\text { 92/43/EEC }\end{array}$ & Bern Convention & IUCN Red List & National list \\
\hline Potamon fluviatile & & & NT & \\
Potamon ibericum & & & NT & Yes \\
Astacus astacus & V & III & VU & Yes \\
Austropotamobius torrentium & II/V & III & DD & \\
Atyaephyra stankoi & & & LC & \\
\hline
\end{tabular}

The scarce knowledge of its ecology and biology, and the lack of economic value, significantly contributed to its low level of protection. The Macedonian law (Official Gazette of the Republic of Macedonia no. 139/2011, 2011) does not mention this species as a threatened one [33]. However, it is strange that despite intensive research in the macroinvertebrate fauna of Dojran Lake (Macedonia) during 2015-2016 (Slavevska-Stamenković, unpublished data) the presence of specimens of $A$. stankoi has not been registered, which indicates an urgent implication of conservation measures.

Acknowledgements. We would like to thank to all colleagues mentioned in Material and Methods and in other chapters for providing specimens for this study.

\section{REFERENCES}

[1] K. A. Crandall, J. E. Buhay, Global diversity of crayfish (Astacidae, Cambaridae, and Parastacidae - Decapoda) in freshwater, Hydrobiologia, 595 (1) (2008), pp. 295-301.

[2] D. C. Yeo, N. Cumberlidge, S. Klaus, Preface freshwater decapod biology in the 21st century, In: Advances in Freshwater decapod systematics and biology, D. Yeo, N. Cumberlidge, S. Klaus, (Eds), Brill, Leiden, Boston, 2014, pp. 1-6.

[3] S. De Grave, Atyaephyra stankoi, The IUCN Red List of Threatened Species, 2013, pp. 1-7.

[4] D. C. Yeo, P. K. Ng, N. Cumberlidge, C. Magalhaes, S. R. Daniels, M. R. Campos, Global diversity of crabs (Crustacea: Decapoda: Brachyura) 
in freshwater, Hydrobiologia, 595 (1) (2008), pp. 275-286.

[5] H. Balss, Süsswasserdecapoden aus Mazedonien, Zool. Anzeig., Leipzig, LXXV (1928), 5/6.

[6] S. Karaman, Die Potamobiden Jugoslaviens, Glasnik Zemaljskog Muzeja Sarajevo, 41 (1) (1929), pp. 147-150.

[7] M. Karaman, Ein Beitrag zur Systematik der Astacidae (Decapoda), Crustaceana, 3 (1962), pp. 173-191.

[8] M. Karaman, Studie der Astacidae (Crustacea, Decapoda), II. Teil: Hydrobiologia, 22 (1963), pp. 111-132.

[9] H. Albrecht, Das System der europäischen Flusskrebse (Decapoda, Astacidae): Vorschlag und Begründung, Mitteilungen aus dem Hamburgischen Zoologischen Museum und Institut, 79 (1982), pp. 187-210.

[10] D. M. Holdich, P. Haffner, P. Y. Noe, Species files, In: Atlas of Crayfish in Europe, C. SoutyGrosset, D. M. Holdich, P. Y. Noe, J. D. Reynolds, P. Haffner, (Eds), Museum National d'Histoire Naturelle, Paris, 2006, pp. 56-131.

[11] P. Śmietana, H. K.Schulz, S. Keszka, R. Schulz, A proposal for accepting Pontastacus as a genus of European crayfish within the family Astacidae based on a revision of the West and East European taxonomic literature, Bulletin Francais de la Peche et de la Pisciculture, 380-381 (2006), pp. 1041-1052.

[12] M. Karaman, Faune de Macedoine, II (Decapoda), Musée D'histoire Naturalle de Skopje, Skopje, 1976. (In Macedonian)

[13] G. Preitzmann, Die mediterranen und vorderasiatischen Sòsswasserkrabden (Potamoniden), Naturhist. Mus., Wien, 1962.

[14] R. Bott, Potamiden aus Afghanistan, Westasien und dem Mittelmeerraum,Vid. Medd. dansk. natur. Foren. Kobenhavn, 1967, pp.1-130.

[15] M. Karaman, Über eine neue Sòsswassergarnelenunterart Atyaephyra desmaresti stankoi n. ssp. (Decapoda, Atyidae) aus Mazedonien, Fragmenta balcanica, Skopje, 9 (8) (1972), pp. 81-84.

[16] M. Christodoulou, A. Antoniou, A. Magoulas, A.Koukouras, Revision of the freshwater genus Atyaephyra (Crustacea, Decapoda, Atyidae) based on morphological and molecular data, ZooKeys, 229 (2012), pp. 53-110.

[17] J. E. García Muñoz, J. E. García Raso, A. Rodríguez, J. A. Cuesta, Cryptic speciation of Greek populations of the freshwater shrimp genus Atyaephyra de Brito Capello, 1867 (Crustacea, Decapoda), evidence from mitochondrial DNA, Zootaxa, 3790 (3) (2014), pp. 401-424.

[18] S. Hristovski, V. Slavevska-Stamenković, N. Hristovski, K. Arsovski, R. Bekchiev, D.
Chobanov, I. Dedov, D. Devetak, I. Karaman, D. Kitanova, M. Komnenov, T. Ljubomirov, D. Melovski, V. Pešić, N. Simov, Diversity of invertebrates in the Republic of Macedonia, Macedonian Journal of Ecology and Environment, 17 (1) (2015), pp. 5-44.

[19] L. Pârvulescu, Crayfish Field Guide of Romania, Bioflux, Cluj-Napoca, 2010, pp. 1-28.

[20] A. Zaikov, An illustrated key to the Bulgarian freshwater crayfish species of family Astacidae (Crustacea: Decapoda), ZooNotes, 13 (2010), pp. $1-4$.

[21] Y. de Jong, M. Verbeek, V. Michelsen, P. de Place Bjørn, W. Los, F. Steeman, N. Bailly, C. Basire, P. Chylarecki, E. Stloukal, G. Hagedorn, F. T. Wetzel, F. Glöckler, A. Kroupa, G. Korb, A. Hoffmann, C. Häuser, A. Kohlbecker, A. Müller, A. Güntsch, P. Stoev, L. Penev, Fauna Europaeaall European animal species on the web, Biodiversity Data Journal 2, (2014).

[22] R. Jesse, C. D. Schubart, S. Klaus, Identification of a cryptic lineage within Potamon fluviatile (Herbst) (Crustacea: Brachyura: Potamidae), Invertebrate Systematics, 24 (4) (2010), pp. 348-356.

[23] R. Jesse, M. Pfenninger, S. Fratini, M. Scalici, B. Streit, C. D. Schubart, Disjunct distribution of the Mediterranean freshwater crab Potamon fluviatilenatural expansion or human introduction?, Biological Invasions, 11 (10) (2009), pp. 2209-2221.

[24] N. Cumberlidge, Potamon ibericum, The IUCN Red List of Threatened Species, 2008, pp. 1-10.

[25] S. Barbaresi, S. Cannicci, M. Vannini, S. Fratini, Environmental correlates of two macro-decapods distribution in Central Italy: Multi-dimensional ecological knowledge as a tool for conservation of endangered species, Biological Conservation, 136 (3) (2007), pp. 431-441.

[26] L. B. Holthuis, Report on a collection of Crustacea Decapoda and Stomatopoda from Turkey and the Balkans, Zool. Verhang., (1961), pp. 1-47.

[27] M. A. Subchev, S. R. Gelder, Branchiobdellida (Annelida: Clitellata) found in the crayfish collection of the Natural History Museum in Vienna, Austria, with a re-description of Branchiobdella papillosa Nesemann \& Hutter, 2002, Acta zoologica bulgarica, 62 (1) (2010), pp. 33-42.

[28] A. Kouba, A. Petrusek, P. Kozák, Continentalwide distribution of crayfish species in Europe: update and maps. Knowledge and Management of Aquatic Ecosystems, 413 (05) (2014).

[29] C. Souty-Grosset, D. M. Holdich, P. Noel, J. C. Reynolds, P. Hafner (eds), Atlas of Crayfish in Europe, Museum national d'Histoire naturelle, Paris, 2006 (Patrimoines naturels, 64), pp. 1-187.

[30] A. Schrimpf, H. K.Schulz, K. Theissinger, L. Pârvulescu, R. Schulz, The first large-scale genetic analysis of the vulnerable noble crayfish Astacus 
astacus reveals low haplotype diversity in central European populations, Knowledge and Management of Aquatic Ecosystems, 401 (2011), pp. 1-35.

[31] I. Papavlasopoulou, C. Perdikaris, L. Vardakas, I. Paschos, Enemy at the gates: introduction potential of non-indigenous freshwater crayfish in Greece via the aquarium trade, Central European Journal of Biology, 9 (1) (2014), pp. 11-18.

[32] L. Edsman, L. Füreder, F. Gherardi, \& C. SoutyGrosset, Astacus astacus, The IUCN Red List of Threatened Species, (2010), pp. 1-18.

[33] Lists for Designation of Strictly Protected and Protected Wild Species in the Republic of Macedonia, 2011, Official Gazette of the Republic of Macedonia no. 139/2011.

[34] A. Schrimpf, K. Theissinger, J. Dahlem, I. Maguire, L. Pârvulescu, H. K. Schulz, R. Schulz, Phylogeography of noble crayfish (Astacus astacus) reveals multiple refugia, Freshwater biology, 59 (4) (2014), pp. 761-776.

[35] M. A. Subchev, Branchiobdellidans (Annelida: Clitellata) found in the crayfish and annelid collections of the Natural History Museum of Humboldt University, Berlin, Germany, Acta zoologica bulgarica, 59 (3) (2007), pp. 275-282.

[36] C. D. Schubart, M. G. J. Huber, Genetic comparisons of German populations of the stone crayfish, Austropotamobius torrentium (Crustacea: Asta- cidae), Bulletin Français de la Pêche et de la Pisciculture, 380-381 (2006), pp. 1019-1028.

[37] L. Füreder, F. Gherardi, \& C. Souty-Grosset, Austropotamobius torrentium, The IUCN Red List of Threatened Species, (2010), pp. 1-12.

[38] M. Todorov, V. Antonova, Z. Hubenov, M. Ihtimanska, L. Kenderov, T. Trichkova, E. Varadinova, C. Deltshev, Distribution and Current Status of Stone Crayfish Populations Austropotamobius torrentium (Decapoda: Astacidae) in Natura 2000 Protected Areas in Bulgaria, Acta Zoologica Bulgarica, 66 (2) (2014), pp. 181-202.

[39] C. Chucholl, A. Schrimpf, The decline of endangered stone crayfish (Austropotamobius torrentium) in southern Germany is related to the spread of invasive alien species and land-use change, Aquatic Conservation: Marine and Freshwater Ecosystems, 26 (1) (2016), pp. 44-56.

[40] J. Šapkarev, P. Angelovski, R. Papović, Animal settlement on the macrophytitic vegetation of Dojran Lake, Annuaire de la Faculté des Sciences d'Université de Skopje, 41-42 (1990), pp. 63-91.

[41] J. E. García Muñoz, A. Rodríguez, J. E. García Raso, J. A. Cuesta, Genetic evidence for cryptic speciation in the freshwater shrimp genus Atyaephyra de Brito Capello (Crustacea, Decapoda, Atyidae), Zootaxa, 2025 (2009), pp. 32-42.

\title{
КАТАЛОГ НА СЛАТКОВОДНИ РАКОВИ (DECAРОDА: POTАМОNIDAE, ASTACIDAE, АTYIDАЕ) ОД РЕПУБЛИКА МАКЕДОНИЈА ВО КОЛЕКЦИЈАТА НА ПРИРОДОНАУЧНИОТ МУЗЕЈ НА МАКЕДОНИЈА
}

\section{Валентина Славевска-Стаменковиќ ${ }^{1}$, Билјана Римческа ${ }^{1}$, Емилија Стојкоска ${ }^{2}$, Наташа Стефановска ${ }^{2}$, Јелена Хиниќ ${ }^{1}$, Васил Костов ${ }^{3}$}

\author{
${ }^{1}$ Институт за биологија, Природно-математички факултет, Универзитет „Св. Кирил и Методиј“, \\ Скопје, Република Македонија \\ ${ }^{2}$ Природонаучен музеј на Македонија, Скопје, Република Македонија \\ ЗЗавод за рибарство, Институт за сточарство, Универзитет „Св: Кирил и Методиј“, \\ Скопје, Република Македонија
}

Каталогот ги сумира податоците од колекцијата на декаподни ракови депонирана во Природонаучниот музеј на Македонија, Скопје, Република Македонија. Во трудот е даден и критички осврт на историските податоци за појавата и дистрибуцијата на декаподните претствници кои се среќаваат во земјата. Популациите на декаподните ракови на територијата на Македонија, до денес не биле контиунирано проучувани, така што овој каталог може да послужи како важен извор на податоци за зачувување и заштита на декаподните ракови и нивните живеалишта.

Клучни зборови: каталог; Decapoda; Природонаучен музеј на Македонија; Македонија 
